\title{
Feeding habits of five dominant fish species from Matang Mangrove Estuaries, Malaysia based on stomach contents and stable isotope analyses
}

\section{K. Mohd Azim}

Universiti Putra Malaysia

S. M. Nurul Amin ( $\nabla$ smnabd@gmail.com )

Universiti Putra Malaysia https://orcid.org/0000-0003-1489-4191

D. Mazumder

ANSTO: Australian Nuclear Science and Technology Organisation
A. Arshad
Universiti Putra Malaysia
F. M. Yusoff
Universiti Putra Malaysia

\section{N. Saintilan}

Macquarie University

\section{Research Article}

Keywords: Matang mangrove, fish, diet, season, stable isotopes

Posted Date: May 14th, 2021

DOl: https://doi.org/10.21203/rs.3.rs-388172/v1

License: (c) (i) This work is licensed under a Creative Commons Attribution 4.0 International License. Read Full License 


\section{Abstract}

The centres of mangrove biodiversity and productivity have been under-represented in studies of fish diet and habitat utilization, particularly in relation to environmental changes between wet and dry seasons. Feeding habits of five dominant fish species (Thryssa kammalensis, Ambassis gymnocephalus, Escualosa thoracata, Stolephorus baganensis and Johnius belangerii) were investigated from two sites in the Matang Mangrove ecosystem, Perak Malaysia, with sampling encompassing both wet and dry seasons. The stomach fullness of the fish was on average significantly higher in the wet season (48\%) than in the dry season (32\%) with isopods and copepods forming a more important component of the fish diet during the wet season than the dry season. The stomach contents of each species were, on average: $T$. kammalensis $\{($ Animal based $(A)=50.11 \%$, Plant based $(P)=$ $38.24 \%)$, A. gymnocephalus $(\mathrm{A}=50.35 \%, \mathrm{P}=37.99 \%)$, E. thoracata $(\mathrm{A}=42.09 \%, \mathrm{P}=44.4 \%)$, S. baganensis $(\mathrm{A}=38.17 \%, \mathrm{P}=$ $46.55 \%)$ and $\mathrm{J}$. belangerri $(A=25.35 \%, P=58.86 \%)$. Therefore, all five fish species can be considered omnivorous. The similarity among diets varied from $60-80 \%$ during the wet and dry season. During the dry season, stable carbon and nitrogen isotope values of the samples had less variation, indicating narrow dietary sources compared to the wet season where the distribution of their isotopic values was larger. Seasons should be considered for planning mangrove management, as results of this study found contracted trophic breadth for commercially valuable fish in the dry season.

\section{Introduction}

The relatively high abundance and diversity of fish within mangroves (Nagelkerken et al. 2008; Whitfield et al. 2017) suggests a preferential use of mangrove forests as nursery areas (Blaber 2007), particularly given the prevalence of juvenile fish compared to adjacent estuarine habitats (Hindel and Jenkens 2004; Sheaves et al. 2015). However, the literature has been biased towards studies in Australia and the United States (Whitfield et al. 2017) with less consideration given to the global centres of mangrove biodiversity and productivity in tropical SE Asia. Recent Malaysian studies have stressed the importance of fish movements between nearshore feeding habitats (Le et al. 2020) with larger juvenile fish moving to the mangrove fringe during high tide periods to prey on mangrove infauna (Le et al. 2018), in common with subtropical systems (Saintilan et al. 2007), with which they share trophic structural similarities (Mazumder et al. 2019).

Seasonal variability in fish visitation and habitat use in mangrove ecosystems may be more important than diel variability. This is true of subtropical systems subject to thermal controls restricting fish recruitment in winter months, both in the Northern Hemisphere (Wu et al. 2018) and Southern Hemisphere (Mazumder et al. 2005). Tropical wet-dry cycles control the input of nutrients and turbidity from the catchment (Schlacher et al. 2008) and influence thermal and salinity conditions important to the distribution of marine fishes. Seasonal variability in the availability of zooplankton has been linked to recruitment of juvenile fish into mangroves of tropical northern Australia (Robertson and Duke 1987, 1990). This may also be why fish in northern Brazilian estuaries show strong recruitment into mangrove creeks at the onset of the rainy season (Barletta et al. 2003). Previous Malaysian studies have considered diet during the dry season only (Le et al. 2018, 2020). However, one of the most important aspects affecting fish population dynamics is the abundance and availability of food items for fish species in this habitat (Faunce and Serafy 2006) which vary between wet and dry phases. Knowledge of feeding habits of these fish is an indispensable tool in the categorization of fish with respect to their diets and mode of feeding (Allison and Sikoki 2013). The food habits of fish species are fundamental when selecting fish for culturing to prevent competition, which may vary due to seasonal changes in food and between species (Das et al. 2012). In addition, information obtained from feeding habits would be applicable for the protection of the species and the ecosystem at large (Turan et al. 2005; Alhassan and Ansu-Darko 2011).

The standard method of determining diet is through the analysis of stomach contents (Manon and Hossain 2013), which classifies the diet through macroscopic and microscopic examination (Hyslop 1980) and highlights the abundance of each food item found within the stomach integrated over a few hours (Mohan and Sankaran 1988). There is an emerging trend of using stable isotope analysis (SIA) as an alternative or in conjunction with stomach content analysis (West et al. 2003), which integrates food consumption over longer periods (Lewis et al. 2001). As organisms consume sources of stable carbon and nitrogen, the isotopic values are transferred to the consumer in a predictable manner (Fry 2006). SIA can be used to determine the pattern or trend of dietary preferences of samples, and can determine the diets with a higher accuracy (Peterson 1999) as not all 
items ingested are incorporated into animal tissue. In most circumstances, SIA is used to calculate the values of stable carbon $\left(\delta^{13} \mathrm{C}\right)$ and nitrogen $\left(\delta^{15} \mathrm{~N}\right)$ in organisms (Livingstone 2002).

Matang mangrove estuaries, are situated at the northern part of Peninsular Malaysia and comprised of mudflats and tidal forested areas (Gan, 1995). There are approximately 8,653 ha of mudflats adjoining the mangrove forest in the foreshore and between islands (Sasekumar et al. 1994). About $85 \%$ of the forests are productive forests (logging and timber activities) while the remaining $15 \%$ are used for aquaculture purposes, where numerous rivers and waterways have shown to be important nursery areas for commercially-valuable marine organisms like fish and prawns (Sasekumar et al. 1994; Chong 2006; Chew et al. 2007). The coastal area (<30 nautical miles from shore) is a major contributor to the total annual marine production in Peninsular Malaysia (Anon 2009), and this location has been the subject of numerous studies to elucidate the importance of the environment across various fields of fisheries (Sasekumar et al. 1994; Chong et al. 2001; Ahmad Adnan et al. 2002; Chong 2007; Chew and Chong 2011; Mohd Azim et al. 2017). A limitation in these studies is the lack of stomach content and stable isotope analyses, which are still scarce in Malaysia and neighbouring countries. This is unfortunate because a thorough understanding of the food web and trophic linkages of fish and their dependence on mangroves is not possible without a complete knowledge of their feeding history. The lack of food and feeding habit studies is mainly due to the number of samples needed, the timeconsuming examination of fish samples, and the cost of analysing samples using stable isotope procedures. Although there have been several studies examining the stable isotopes of fish in Matang mangrove estuaries (Kiso and Mahyam 2003; Tanaka et al. 2011), they only cover a few targeted species, nor did sampling span the full range of wet and dry season conditions.

The objective of the present study is to expand the previous findings by observing the feeding habits of five dominant fish species, based on stomach contents and stable isotope analyses, documenting changes in stomach fullness and diet composition in wet and dry seasons.. We hypothesize that stomach fullness will be greater and dietary breadth broader during the wet season, corresponding to high productivity and the recruitment of additional food items during this period. This will reveal the primary sources of autotrophic production for these species and the trophic linkages within the marine-mangrove food web of the Matang mangrove estuary.

\section{Materials And Methods}

\section{Study Area}

The study was conducted in the estuarine waters of Matang mangrove forest reserve (MMFR), Perak, Peninsular Malaysia (Fig.1) between September 2015 and August 2016. This area forms a large crescent-shaped strip along the northern coast of Perak state, stretching as far as $51.5 \mathrm{~km}$ from Kuala Gula $\left(4^{\circ} 55^{\prime} \mathrm{N}, 100^{\circ} \mathrm{E} 25^{\prime}\right)$ to the north and to Bagan Panchor $\left(4^{\circ} 40^{\prime} \mathrm{N}, 100^{\circ} \mathrm{E} 40^{\prime}\right)$ to the south measuring about $13 \mathrm{~km}$ wide. Matang mangrove is built on deltaic islands (Gula Island, Kelumpang Island, Selinsing Island, Sangga Kecil Island, Sangga Besar Island, Terong Island and Pasir Hitam Island) criss-crossed by major mangrove channels (Tinggi River, Tiram River, Sepetang River, Terusan Gula River, Selinsing River, Sangga Besar River, Sangga Kecil River, Jaha River and Jarum Mas River).

\section{Sample Collection}

Fish samples were obtained from local fishermen who operated push net boats in MMFR areas as their main source of income. This medium size of motorized boat was operated by using trawling method but unlike any other common trawling boat, the net was attached at the front side of the boat, with the net specification of $14.0-15.0 \mathrm{~m}$ in length, $2.0-5.0 \mathrm{~m}$ in width, and $2.5-$ $5.0 \mathrm{~cm}$ in mesh sizes. Usually, the fishermen caught the fish during daylight when the tides were high. Five dominant fish species, namely Escualosa thoracata, Thryssa kammalensis, Ambassis gymnocephalus, Stolephorus baganensis and Johnius belangerii were selected for this study as they the were the most abundand species in the area. The sample sizes of the collected samples ranged from $5.0 \mathrm{~cm}-20.0 \mathrm{~cm}$.

For stomach content and stable isotope analyses, five most dominant species were collected from two stations (fish landing

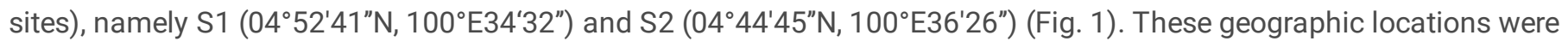
considered sufficient enough in covering all fish species available in the study area. The climate in MMFR and the surrounding 
area consisteds of two main seasons, the wet season from November until January and the dry season between February and April. Five replicate $(n=5)$ samples for each species were collected twice during each season at study sites to obtain the required number of samples.

\section{Stomach Fullness and Content Analysis}

In the laboratory, fish samples were cleaned and surface moisture was blotted out using tissue paper. For each fish, the standard and total lengths were measured and dissected using a dissection kit to remove the stomach. The degree of stomach fullness was observed and recorded. This was done using an empirical scale (Table 1). The stomach was then preserved in $5 \%$ formalin for further study.

Examination of the stomach content was done within 2-3 days of preservation. Prior to stomach examination, the stomach was cleaned and excess moisture blotted out using tissue paper. The stomach was then dissected, and its contents weighed to the nearest $0.01 \mathrm{~g}$ using a digital weighing balance (Model- AY220, Shimadzu Corporation, Japan). The stomach contents were examined both macroscopically, and microscopically under a microscope (Model- EMT 21444, Labax Co, Japan), for taxonomic classification and identification of the various food items with the aid of standard reference texts of Lovett (1981); Seng, (1994) and Tan and $\mathrm{Ng}$ (1994).

The analysis of the stomach content was done using the percentage frequency of occurrence $\left(\mathrm{F}_{p \mathrm{i}}\right)$ and percentage numerical abundance $\left(C_{i}\right)$ for each prey item, according to the method by Chrisfi et al. (2007):

Percentage frequency of occurrence $\left(\mathrm{F}_{p \mathrm{i}}\right)=\left(\mathrm{N}_{1 i} / \mathrm{N}_{\mathrm{p}}\right) \times 100$

where:

$\mathrm{N}_{1 i}=$ number of stomach of which food item $i$ was found

$N_{p}=$ number of non-empty stomach

Percentage numerical abundance $\left(\mathrm{C}_{i}\right)=n i / \sum_{\mathrm{i}=1}^{\mathrm{ni}_{\mathrm{i}}} \times 100$

where:

$n i=$ number of $i$-th food item

$m=$ number of food items

The relative importance of prey in the diets of the five dominant fish species in the Matang mangrove estuaries was examined by the simple resultant index (\% Rs) according to Mohan and Sankaran (1988) as follows:

Simple Resultant Index (\% Rs) $=$

$$
\frac{\sqrt{C_{i}^{2}+F_{p i}^{2}}}{\sum_{i=1}^{m} \sqrt{C_{i}^{2}+F_{p i}^{2}}} \times 100
$$

abundance and $\mathrm{F}_{p \mathrm{i}}$ is the percentage frequency of occurrence.

Where $\mathrm{C}_{i}$ is the percentage numerical

Multivariate techniques in PRIMER v7 software (Clarke and Gorley 2015) were used to compare stomach fullness and food items composition among major species. The numerical abundance of the identified stomach fullness and food items were square root transformed and a similarity matrix based on the Bray-Curtis similarity index was then constructed and subjected to hierarchical agglomerative clustering (group average linkage) and non-metric multidimensional scaling (nMDS) ordination (Clarke et al. 
2014). To assess the composition of food items across seasons, a shade plot was produced by clustering the major species on the $x$-axis based on Bray-Curtis similarity, with the most common and abundant food items on the $y$-axis (Clarke and Gorley, 2015). The similarity profile test (SIMPROF) was applied to determine the significant differences among clusters (Clarke et al. 2008).

\section{Stable Isotope Analysis}

Sample processing was undertaken in a filtered-air room laboratory and powder-less laboratory gloves were worn at all times to minimise contamination. The fish brought in from the field were washed with distilled water and kept frozen until processed. White muscle tissue from the dorsal region of fish was collected, as this tissue has been shown to be representative of overall stable isotope signatures in fish and to be less variable than other tissues (Hesslein et al. 1993; Pinnegar and Polunin 1999). Lipid extractions were not undertaken, as delipidation from muscle tissue appears to lead to only small (1\%) isotope shifts in $\delta^{13} \mathrm{C}$ and $\delta^{15} \mathrm{~N}$ values (Sotiropoulos et al. 2004). Muscle tissue samples were dried at $60^{\circ} \mathrm{C}$ for 72 hours and then ground to a fine powder with a mortar and pestle. $0.5 \pm 0.05 \mathrm{mg}$ powdered and homogenised whole-body samples were loaded into tin capsules and were analysed with a continuous flow isotope ratio mass spectrometer (CF-IRMS; Model Delta V Plus; Thermo Scientific Corporation, Waltham, MA, USA) that was interfaced to an elemental analyser (Thermo Fisher Flash 2000 HT EA; Thermo Electron Corporation, Waltham, MA, USA) at ANSTO. Data were reported relative to IAEA secondary standards certified relative to VPDB for carbon and air for nitrogen. A two-point calibration was employed to normalize the isotope data, utilizing standards that bracket the samples being analyzed. Two quality control reference samples were also included in each run. Results were accurate to $+/-1 \%$ for both $\% \mathrm{C}$ and $\% \mathrm{~N}$ and $+/-0.3$ parts per thousand for $\delta^{13} \mathrm{C}$ and $\delta^{15} \mathrm{~N}$. Stable isotope values were reported in delta (d) units in parts per thousand (\%o) relative to the international standard and determined as follows:

$$
X(\%)=\left(\frac{R_{\text {sample }}}{\mathrm{R}_{\text {standerd }}}-1\right) \times 1000
$$

where $\mathrm{X}=\delta^{13} \mathrm{C}$ or $\delta^{15} \mathrm{~N}$, and $\mathrm{R}={ }^{13} \mathrm{C} /{ }^{12} \mathrm{C}$ or ${ }^{15} \mathrm{~N} /{ }^{14} \mathrm{~N}$, respectively. Since the lipid content of tissue is related to the molar ratio of carbon to nitrogen $(\mathrm{C}: \mathrm{N})$, when $\mathrm{C}: \mathrm{N}$ was $>3.5$ (e.g. high lipid content), the lipid content for muscle

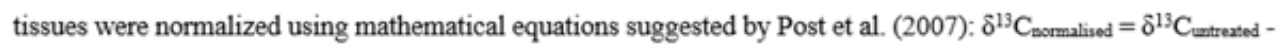
$3.32+0.99 \times \mathrm{C}: \mathrm{N}$.

\section{Results}

\section{Stomach fullness}

Overall, the mean percent of stomach fullness of five dominant fish species varied between seasons (Table 2). However, similarities were found for stomach fullness between wet and dry season; $91.08 \%, 84.80 \%, 82.30 \%, 68.48 \%$ and $65.52 \%$ for $S$. baganensis, E. thoracata, T. kammalensis, J. belangerii and A. gymnocephalus, respectively. Additionally, the cluster analysis showed more than $80 \%$ similarity of stomach fullness among the $S$. baganensis, E. thoracata and T. kammalensis between wet and dry seasons, while the other two species (A. gymnocephalus and J. belangerii) were less than $70 \%$ similar between the two seasons. The Multi-Dimensional Scaling (MDS) ordination analyses showed three distinct groups at $80 \%$ similarity with empty stomach found only in A. gymnocephalus and S. baganensis during both seasons (Fig. 2).

\section{Diet composition}

Analyses of the different prey items by using simple resultant index (\% Rs) on the five dominant fish species revealed 19 important items belonging to three major groups: plant based diets, animal based diets and debris (Table 3). According to \% Rs, plant based (phytoplankton, algae and plant leave) and animal based (zooplankton, unidentified fish parts, fish \& crustacean parts) diets varied between wet and dry seasons for all species. Higher \%Rs animal diets were found for E. thoracata, $T$. kammalensis and S. baganensis respectively in the dry season. J. belangerii had higher \%Rs animal diet in both wet and dry seasons. A. gymnocephalus consumed higher \% Rs in plant and debris materials compared to other species in both wet and dry 
seasons, respectively (Table 3). All these species consuming $\mathrm{d}$ both plant and animal diets in both wet and dry seasons indicate their omnivore feeding status. The highest similarity (89.37\%) of diet composition was observed between A. gymnocephalus and S. baganensis, while the lowest similarity (77.45\%) was found between J. belangerii and E. thoracata. Overall, there was an $80 \%$ similarity among the five dominant species according to MDS analysis (Fig. 3).

\section{Variation of prey between wet and dry season}

Similarities of diet composition between wet and dry season were $85.05 \%, 77.40 \%, 72.25 \%, 70.28 \%$ and $60.03 \%$ for $S$. baganensis, J. belangerii, T. kammalensis, E. thoracata and A. gymnocephalus, (Fig. 4) respectively. The highest similarity (85.05\%) of diets between wet and dry season was observed in S. baganensis, while the lowest similarity (60.03\%) was found in A. gymnocephalus. For inter-species comparison, diets similarity of E. thoracata and T. kammalensis was at $80 \%$ in the wet season indicating that both species share $80 \%$ similar diets in the wet season (Fig. 5). Additionally, the diet similarity of $S$. baganensis and A. gymnocephalus was also $80 \%$ in the dry season, suggesting higher competition for these species in getting food. Overall there was $60 \%$ similarity of diets between wet and dry season for four species except S. baganensis (Fig. 5)

\section{Food web for five major fish species}

In the dry season, stable carbon and nitrogen isotope values of five major species had narrow distribution (range from - $19.20 \%$ o to $-20.96 \%$ or for $\delta^{13} \mathrm{C}$ and from $12.96 \%$ o to $13.64 \%$ o for $\delta^{15} \mathrm{~N}$ ) indicating a smaller dietary diversity compared to the wet season where the distribution of their isotopic values were larger (Fig. 6). In the dry season, $\delta^{13} \mathrm{C}$ and $\delta^{15} \mathrm{~N}$ values of the species were more enriched compared to the wet season. The only exception was $S$. baganesis, where the $\delta^{13} \mathrm{C}$ value was enriched in the wet season. Among the five species analysed, an obvious dietary shift was observed for E. thoracata and A. gymnocephalus (Fig. 6). The isotopic shift of E. thoracata was $3.3 \%$ for $\delta^{13} \mathrm{C}$ and $2.3 \%$ for $\delta^{15} \mathrm{~N}$ and for $A$. Gymnocephalus, this isotopic shift was $2.6 \%$ for both $\delta^{13} \mathrm{C}$ and $\delta^{15} \mathrm{~N}$ in the wet season. In the wet season, the $\delta^{13} \mathrm{C}$ and $\delta^{15} \mathrm{~N}$ values of $E$. Thoracata and $A$. Gymnocephalus were more depleted, suggesting a higher intake of mangrove sourced materials in the diet.

\section{Discussion}

Wet-dry seasonal cycles are characteristic of tropical mangrove coastlines in northern Australia, Indo-china, western Africa, Central and Southern America and parts of North America (Abrantes et al. 2015). Characterisation of the composition and structure of mangrove food-webs must therefore consider changes driven by seasonal climate, and the potential influence of zooplankton recruitment, autotroph productivity and halo-thermal habitat availability. Greater abundance of fish in mangrove creeks during the wet season has been observed in Thailand (Ikejima et al 2003), northern Australia (Robertson and Duke 1990) and Brazil (Barletta et al. 2003). Fish in small northern Australian estuaries subjected to wet-dry seasonality showed greater diet similarity in the wet season than the dry season (Abrantes et al. 2015).

The stomach fullness of five dominant fish species of the Matang estuary mangrove forest was higher in the wet season (48\%) than the dry season (32\%). This pattern might be due to the fact that longer rain duration washed a higher abundance of food sources from upstream to downstream compared to the dry season, and the increased occurrence of zooplankton in the estuary during the wet season. Isopods and copepods formed more important components of the fish diet during the wet season compared to the dry season (Table 3). This finding is in agreement with studies from the Bay of Bengal (Bangladesh), KwaZulu Natal (South Africa) Marudu Bay (Sabah, Malaysia) which also showed higher variability and abundance of fish during the wet season (Robertson and Duke 1990; Barletta et al. 2003; Nagelkerken et al. 2008) co-incident with increased zooplankton abundance. In arid-zone mangroves, fish abundances may be higher in winter, though this is also co-incident with a greater range of food sources (Shahrika and Fry 2016).

Our study indicates that E. thoracata, T. kammalensis, A. gymnocephalus, S. baganensis and J. belangerii were omnivores. It is clear that J. belangerii in this study fed on a higher animal based diet (\% Rs $>60 \%$ ) in both seasons than the other four species, confirming its position as the top order predator in the Matang mangrove (Mazumder et al. 2019). This finding is in line with a previous study by Chong (2005), Kiso and Mahyam (2003) and Tanaka et al. (2011) which stated that the coastal and estuarine 
areas in Peninsular Malaysia especially in the Straits of Malacca were predominantly inhabited by either carnivorous or omnivorous fish that depend highly on smaller items of animal derivatives as their main source of diet.

The stable carbon and nitrogen isotope values of the five species clustered closely in the dry season and had narrow distribution suggesting limitation of dietary sources compared to the wet season. Whereas in the wet season, the dietary diversity for the five species have been increased as revealed by their wider distribution of isotopic values. This is most likely due to a higher abundance of dietary materials available for species in the wet season. This is also in agreement with the findings from stomach fullness, which showed a higher occurrence of full stomach during wet season.

A distinct dietary shift was also observed for E. thoracata and A. gymnocephalus. In the wet season, mangrove-sourced materials when compared to the dry season mostly influenced the diet of these two species. It could be assumed that during the wet season, a higher amount of mangrove detritus enter the estuary through flood or rain water from the surrounding mangroves, as indicated by depleted $\mathrm{C}$ and $\mathrm{N}$ isotope ratios for these two species. Previous studies in the same site by Tanaka et al. (2011) and Kiso and Mahyam (2003) showed generally depleted C values in the mangrove estuaries of the targeted fish species because of the higher precipitation during rainy season, which is comparatively similar to the situation in the present study. Furthermore, the findings of this study are also in agreement with the findings of the Australian floodplain study where food supplies in flood plain habitats were restricted during dry conditions and species dietary richness were narrowed down (Mazumder et al. 2006, 2011). The segregation of trophic components in this cluster analysis is a helpful tool in the development of conceptual models of ecosystem functions in a linked mangrove-estuarine ecosystem (Robinson and Frid, 2003; Marguillier et al. 1997).

\section{Declarations}

Availability of Data and Material: All data produced or analyzed during this study are included in this manuscript.

Code Availability: Not applicable.

Authors' Contribution: M. K. Mohd Azim conducted sampling, laboratory work and wrote the draft manuscript. S. M. Nurul Amin designed the research, supervised and edited the manuscript. D. Mazumder analyzed the samples of stable isotope and edited the manuscript. A. Arshad, F. M. Yusoff provided financial support, checked the analysis and edited the manuscript. N. Saintilan provided critical insights, interpretations and editing to finalize the manuscript.

Funding: This study was financially supported by Universiti Putra Malaysia, Malaysia through the Putra Grant Scheme (GPIPB/2014/9441201).

Ethical Statement: Not applicable

Consent to Participate: Not applicable.

Consent for Publication: Written consent for publication was obtained from all authors.

Conflict of interest / Competing Interests: The authors declare that there is no conflict of interest regarding the publication of this article.

\section{References}

Abrantes KG, Johnston R, Connolly RM, Sheaves M (2015) Importance of mangrove carbon for aquatic food webs in wet-dry tropical estuaries. Estuar Coast 38(1): 383-399

Ahmad Adnan N, Loneragan NR, Connolly RM (2002) Variability of, and the influence of environmental factors on, the recruitment of postlarval and juvenile Penaeus merguiensis in the Matang mangroves of Malaysia. Mar Biol 141: 241-251.

https://doi.org/10.1007/s00227-002-0837-2 
Alhassan EH, Ansu-Darko M (2011) Food and feeding habits of a potential aquaculture candidate, the black Nile catfish, Bagrus bajad in the Golinga reservoir. Aust J Basic Appli Sci 5: 354-359. http://hdl.handle.net/123456789/237

Allison ME, Sikoki FD (2013) Food and feeding habits of Parailia pellucida (Boulenger, 1901) (Schilbeidae) in the freshwater reaches of the nun river of the Niger Delta, Nigeria. Int J Adv Fish Aqua Sci 1: 1-14. http://scientific.cloudjournals.com/index.php/IJAFAS/article/view/Sci-64

Anonymous (2009) Annual Fisheries Statistics, Department of Fisheries Volume 1, Ministry of Agriculture, Kuala Lumpur, Malaysia

Barletta M, Barletta-Bergan A, Saint-Paul U, Hubold G (2003) Seasonal changes in density, biomass, and diversity of estuarine fishes in tidal mangrove creeks of the lower Caeté Estuary (northern Brazilian coast, east Amazon). Mar Ecol Prog Ser 256: 217228

Blaber SJ (2007) Mangroves and fishes: issues of diversity, dependence, and dogma. Bull Mar Sci 80(3): 457-472

Chew LL, Chong VC (2011) Copepod community structure and abundance in a tropical mangrove estuary, with comparisons to coastal waters. Hydrobiologia 666: 127-143.https://doi.org/10.1007/s10750-010-0092-3

Chew LL, Chong VC, Hanamura Y (2007) How important are zooplankton to juvenile fish nutrition in mangrove ecosystems? In Nakamura, K. (Ed.) Sustainable Production Systems of Aquatic Animals in Brackish Mangrove Areas, JIRCAS Working Report No. 56, pp. 7-18

Chong VC (2007) Mangroves-Fisheries Linkages the Malaysian perspective. Bull Mar Sci 80: 755-772

Chong VC (2006) Sustainable utilization and management of mangrove ecosystems of Malaysia. Aquat Ecosyst Health 9(2): 249-260. https://doi.org/10.1080/14634980600717084

Chong VC (2005) Fifteen years of fisheries research in the Matang mangroves: what have we learnt? In Mohamad Ismail S, Muda A, Ujang R, Ali Budin K, Lim KL, Rosli S, Mohd. Som J, Latiff A (Eds.) Sustainable Management of Matang Mangroves: 100 years and Beyond. Forestry Department, Peninsular Malaysia, pp. 411-429

Chong VC, Low CB, Ichikawa T (2001) Contribution of mangrove detritus to juvenile prawn nutrition: a dual stable isotope study in a Malaysian mangrove forest. Mar Biol 138(1): 77-86. https://doi.org/10.1007/s002270000434

Chrisfi P, Kaspiris P, Katselis G (2007) Feeding habits of sand smelt (Atherina boyeri, Risso 1810) in Tichonis Lake (western Greece). J Appl Ichthyol 23:209 -214

Clarke K, Gorley RN (2015) PRIMER v7: User Manual/Tutorial. PRIMER-E Plymouth. larke KR, Gorley RN, Somerfield PJ, Warwick RM. 2014. Change in marine communities: an approach to statistical analysis and interpretation. 3rd ed PRIMER-E, Plymouth

Clarke KR, Somerfield PJ, Gorley RN (2008) Testing of null hypotheses in exploratory community analyses: similarity profiles and biota-environment linkage. J Exp Mar Biol Ecol 366: 56-69. https://doi.org/10.1016/j.jembe.2008.07.009

Das P, Mandal SC, Bhagabati SK, Akhtar MS, Singh SK (2012) Important live food organisms and their role in aquaculture. Front Aqua5(4): 69-86. https://doi.org/10.13140/RG.2.2.21105.07523

Faunce $\mathrm{CH}$, Serafy JE (2006) Mangroves as fish habitat: 50 years of field studies. Mar Ecol Prog Ser 318: 1-18. Doi: https://doi.org/ 10.3354/meps318001

Fry B (2006) Stable isotope ecology. Springer

Gan BK (1995) A working plan for the Matang mangroves forest reserve, Perak (4th Revision). The state government of Perak Darul Ridzuan 
Hesslein RH, Hallard KA, Ramlal P (1993) Replacement of sulfur, carbon, and nitrogen in tissue of growing broad white fish (Coregonus nasus) in response to a change in diet traced by $834 \mathrm{~S}, 813 \mathrm{C}$ and $815 \mathrm{~N}$. Can J Fish Aquat Sci 50: 2071-2076. https://doi.org/10.1139/f93-230

Hindell JS, Jenkins GP (2004) Spatial and temporal variability in the assemblage structure of fishes associated with mangroves (Avicennia marina) and intertidal mudflats in temperate Australian embayments. Mar Biol 144(2): 385-395

Kiso KI, Mahyam MI (2003) Distribution and feeding habits of juvenile and young John's snapper Lutjanus johnii in the Matang mangrove estuary, west coast of Peninsular Malaysia. Fish Sci 69: 563-568. https://doi.org/10.1046/j.1444-2906.2003.00657.x

Le QD, Haron NA, Tanaka K, Ishida A, Sano Y, Dung LV, Shirai K (2017) Quantitative contribution of primary food sources for a mangrove food web in Setiu lagoon from East coast of Peninsular Malaysia, stable isotopic ( $\delta 13 \mathrm{C}$ and $\delta 15 \mathrm{~N})$ approach. Reg Stud Mar Sci 9: 174-179

Le DQ, Fui SY, Tanaka K, Suratman S, Sano Y, Shirai K (2020) Feeding habitats of juvenile reef fishes in a tropical mangroveseagrass continuum along a Malaysian shallow-water coastal lagoon. Bull Mar Sci 96(3): 469-486

Lewis WM, Hamilton SK, Rodriguez MA, Saunders JF, Lasi MA (2001) Food web analysis of the Orinoco floodplain based on production estimates and stable isotope data. J N Amer Benthol Soc 202: 241-254. https://doi.org/10.2307/1468319

Livingston RJ (2002) Trophic Organization in Coastal Systems. CRC Press, p. 408

Lovett DL (1981) A guide to the shrimps, prawns, lobsters, and crabs of Malaysia and Singapore: Faculty of Fisheries and Marine Science, Universiti Pertanian Malaysia

Manon MR, Hossain MD (2013) Food and feeding habit of Cyprinus carpio var. specularis. J Scient Found 9: 163-169. https://doi.org/10.3329/jsf.v9i1-2.14658

Marguillier S, van der Velde G, Dehairs F, Hemminga MA, Rajagopal S (1997) Trophic relationships in an interlinked mangroveseagrass ecosystem as traced by $\delta 13 \mathrm{C}$ and $\delta 15 \mathrm{~N}$. Mar Ecol Prog Ser 151: 115-121. https://doi.org/ $10.3354 / \operatorname{meps} 151115$

Mazumder D, Saintilan N, Williams R (2006) Trophic relationships between itinerant fish and crab larvae in a temperate Australian saltmarsh. Mar Freshwater Res 57: 193-199. https://doi.org/10.1071/MF05040

Mazumder D, Saintilan N, Williams RJ, Szymczak R (2011) Trophic importance of a temperate intertidal wetland to resident and itinerant taxa: evidence from multiple stable isotope analyses. Mar Freshwater Res 62(1): 11-19.

https://doi.org/10.1071/MF10076

Mazumder D, Saintilan N, Yusoff FM, Kelleway JJ (2019) Equivalence of trophic structure between a tropical and temperate mangrove ecosystem in the Indo-Pacific. Mar Freshwater Res 70(10): 1436-1444

Mohan MV, Sankaran TM (1988) Two new indices for stomach content analysis of fishes. J Fish Bio 33: 289-292

Mohd Azim MK, Amin SMN, Romano N, Arshad A, Yusoff FM (2017) Population Dynamics of Yellowtail Scad, Atule mate (Cuvier 1833) in Marudu Bay, Sabah, Malaysia. Sains Malays 46(12): 2263-2271. http://dx.doi.org/10.17576/jsm-2017-4612-02

Nagelkerken I, Blaber SJM, Bouillon S, Green P, Haywood M, Kirton LG, Meynecke JO Pawlik J, Penrose HM, Sasekumar A, Somerfield PJ (2008) The habitat function of mangroves for terrestrial and marine fauna: A review. Aquat Bot 89: 155-185. https://doi.org/10.1016/j.aquabot.2007.12.007

Peterson BJ (1999) Stable isotopes as tracers of organic matter input and transfer in benthic food webs: a review. Acta Oecol Int J Ecol 20: 479-487. https://doi.org/10.1016/S1146-609X(99)00120-4 
Pinnegar JK, Polunin NVC (1999) Differential fractionation of $\delta 13 \mathrm{C}$ and $\delta 15 \mathrm{~N}$ among fish tissues: implications for the study of trophic interactions. Funct Ecol 13: 225-231. https://doi.org/10.1046/j.1365-2435.1999.00301.x

Robertson Al, Duke NC (1987) Mangroves as nursery sites: comparisons of the abundance and species composition of fish and crustaceans in mangroves and other nearshore habitats in tropical Australia. Mar Biol 96(2): 193-205

Robertson Al, Duke NC (1990) Recruitment, growth and residence time of fishes in a tropical Australian mangrove system. Estuar Coast Shelf Sci 31(5): 723-743

Robinson LA, Frid CLJ (2003) Dynamic ecosystem models and the evaluation of ecosystem effects of fishing: can we make meaningful predictions? Aquat Conserv 13: 5-20. https://doi.org/10.1002/aqc.506

Saintilan N, Hossain K, Mazumder D (2007) Linkages between seagrass, mangrove and saltmarsh as fish habitat in the Botany Bay estuary, New South Wales. Wetl Ecol Manag 15(4): 277-286

Sasekumar A, Chong VC, Lim KH, Singh HR (1994) The fish community of Matang mangrove waters. In Sudara S, Wilkinson CR, Chou LM. (Eds.) Proceedings Third ASEAN-Australian Symposium on Living Coastal Resources, Vol. 2, Research Papers, Chulalongkorn University, Bangkok, Thailand, pp. 457-464.

Schlacher TA, Connolly RM, Skillington AJ, Gaston TF (2009) Can export of organic matter from estuaries support zooplankton in nearshore, marine plumes? Aquat Ecol 43(2): 383-393

Seng YT (1994). Molluscs in Malaysia (2nd ed.). Kuala Lumpur Malaysia: Department of Fisheries, Ministry of Agriculture Malaysia.

Shahraki M, Fry B (2016) Seasonal fisheries changes in low-rainfall mangrove ecosystems of Iran. Estuar Coast 39(2): 529-541

Sheaves M, Baker R, Nagelkerken I, Connolly RM (2015) True value of estuarine and coastal nurseries for fish: incorporating complexity and dynamics. Estuar Coast 38(2): 401-414

Sotiropoulos MA, Tonny WM, Wassenaar LI (2004). Effects of lipid extraction on stable carbon and nitrogen isotope analyses of fish tissues: potential consequences for food web studies. Ecol Freshwater Fishn n 13: 155-160. https://doi.org/10.1111/j.16000633.2004.00056.x

Tan CGS, Ng PKL (1994). An annotated checklist of mangrove brachyuran crabs from Malaysia and Singapore. Hydrobiologia 285: 75-84. Doi: https://doi.org/10.1007/BF00005655

Tanaka K, Hanamura Y, Chong VC, Watanabe S, Man A, Kassim FM, Ichikawa T (2011) Stable isotope analysis reveals ontogenetic migration and the importance of a large mangrove estuary as a feeding ground for juvenile John's snapper Lutjanus johnii. Fish Sci 77(5): 809. https://doi.org/10.1007/s12562-011-0396-x

Turan C, Yalcin S, Turan F, Okur E, Akyurt I (2005) Morphometric comparisons of African catfish, Clarias gariepinus, populations in Turkey. Folia Zool 54: 165-172. https://search.proquest.com/docview/206318878?accountid=27932

West JM, Williams GD, Madon SP, Zedler JB (2003) Integrating spatial and temporal variability into the analysis of fish food web linkages in Tijuana Estuary. Environ Biol Fishes 67: 297-309. https://doi.org/10.1023/A:1025843300415

Whitfield AK (2017) The role of seagrass meadows, mangrove forests, salt marshes and reed beds as nursery areas and food sources for fishes in estuaries. Rev Fish Biol Fish 27(1): 75-110

Wu ZQ, Zou Q, Chang T, Zhang D, Huang LL (2018) Seasonal dynamics of the juvenile fish community structure in the Maowei Sea mangroves. PLoS ONE 13(2).

\section{Tables}


Table 1 Empirical scale of stomach fullness separated into five classes as outlined for the study of major five species in the Matang mangrove estuaries, Perak, Malaysia

\begin{tabular}{ll}
\hline $\begin{array}{l}\text { Fullness } \\
\text { classification }\end{array}$ & \multicolumn{1}{c}{ Description } \\
\hline Full stomach & Stomach massively stuffed with enormous amounts of small prey or a few large preys. \\
$\square$ full stomach & Stomach adequately stuffed with substantial amounts of small preys or a few large preys. \\
$\square$ full stomach & Stomach moderately stuffed with adequate amount of prey. \\
$\square$ full stomach & Stomach slightly stuffed with a few or substantial small preys. \\
Empty stomach & Stomach scarcely stuffed with no or/and few small preys. \\
\hline
\end{tabular}

Table 2 Variation of stomach fullness (\%) of five major fish species between wet and dry season in Matang Mangrove Estuaries, Perak, Malaysia

\begin{tabular}{lcccccccccccc}
\hline \multicolumn{1}{c}{ Species } & \multicolumn{1}{c}{ Wet Season } & \multicolumn{1}{c}{ Dry Season } \\
\cline { 2 - 12 } & $\mathrm{N}$ & 1 & $\square$ & $\square$ & $\square$ & 0 & $\mathrm{~N}$ & 1 & $\square$ & $\square$ & $\square$ & 0 \\
\hline E. thoracata & 5 & $70 \%$ & $10 \%$ & $10 \%$ & $10 \%$ & $0 \%$ & 5 & $40 \%$ & $10 \%$ & $20 \%$ & $30 \%$ & $0 \%$ \\
T. kammalensis & 5 & $40 \%$ & $0 \%$ & $50 \%$ & $10 \%$ & $0 \%$ & 5 & $20 \%$ & $20 \%$ & $50 \%$ & $10 \%$ & $0 \%$ \\
\hline A. gymnocephalus & 5 & $30 \%$ & $10 \%$ & $30 \%$ & $20 \%$ & $10 \%$ & 5 & $10 \%$ & $0 \%$ & $70 \%$ & $0 \%$ & $20 \%$ \\
\hline S. baganensis & 5 & $50 \%$ & $20 \%$ & $20 \%$ & $0 \%$ & $10 \%$ & 5 & $30 \%$ & $20 \%$ & $40 \%$ & $0 \%$ & $10 \%$ \\
\hline J. belangerii & 5 & $50 \%$ & $30 \%$ & $20 \%$ & $0 \%$ & $0 \%$ & 5 & $60 \%$ & $0 \%$ & $20 \%$ & $20 \%$ & $0 \%$ \\
\hline \% Mean Occurrence & 100 & $48 \%$ & $14 \%$ & $26 \%$ & $8 \%$ & $4 \%$ & 100 & $32 \%$ & $10 \%$ & $40 \%$ & $12 \%$ & $6 \%$ \\
\hline
\end{tabular}

( $N$, number of fish; 1, full stomach; $\square$, three quarters full stomach; $\square$, half full stomach; $\square$, quarter full stomach; 0 , empty stomach)

Table 3 Simple Resultant Index (\%Rs) of overall diet composition for five major fish species in Matang Mangrove Estuaries, Perak, Malaysia 


\begin{tabular}{|c|c|c|c|c|c|c|c|c|c|c|}
\hline \multirow[t]{2}{*}{ Food Items } & \multicolumn{2}{|c|}{ E. thoracata } & \multicolumn{2}{|c|}{ T. kammalensis } & \multicolumn{2}{|c|}{ A. gymnocephalus } & \multicolumn{2}{|c|}{ S. baganensis } & \multicolumn{2}{|c|}{ J. belangerii } \\
\hline & Wet & Dry & Wet & Dry & Wet & Dry & Wet & Dry & Wet & Dry \\
\hline Plant based diet & & & & & & & & & & \\
\hline $\begin{array}{l}1 . \\
\text { Cosinusdiscus sp. }\end{array}$ & 17.00 & 9.42 & 17.00 & 8.40 & 5.50 & 11.00 & 22.86 & 14.70 & 3.05 & 0.00 \\
\hline 2. Navicular sp. & 12.69 & 0.00 & 5.06 & 2.98 & 9.08 & 9.05 & 3.89 & 0.00 & 0.00 & 0.00 \\
\hline 3. Achanthes sp. & 0.00 & 8.17 & 3.18 & 5.75 & 0.00 & 11.21 & 0.00 & 13.78 & 0.00 & 2.61 \\
\hline 4. Pinnularia sp. & 0.00 & 7.31 & 0.00 & 0.00 & 0.00 & 11.92 & 0.00 & 4.71 & 0.00 & 0.00 \\
\hline $\begin{array}{ll}\text { 5. } & \text { Pleurosigma } \\
\text { sp. } & \end{array}$ & 1.81 & 0.00 & 0.00 & 0.00 & 0.00 & 0.00 & 0.00 & 0.00 & 0.00 & 0.00 \\
\hline 6. Plant leaves & 9.89 & 31.09 & 20.43 & 24.63 & 37.64 & 3.96 & 7.14 & 3.68 & 20.00 & 18.10 \\
\hline Total & 41.39 & 55.99 & 45.67 & 41.76 & 52.22 & 47.14 & 33.89 & 36.87 & 23.05 & 20.71 \\
\hline $\begin{array}{l}\text { Animal based } \\
\text { diet }\end{array}$ & & & & & & & & & & \\
\hline 7. Mysid & 0.00 & 2.40 & 5.38 & 3.12 & 7.50 & 11.21 & 4.60 & 17.12 & 0.00 & 0.00 \\
\hline 8. Amphipod & 5.87 & 6.06 & 8.14 & 6.41 & 0.00 & 15.68 & 13.21 & 11.50 & 2.30 & 17.69 \\
\hline 9. Copepod & 0.00 & 0.00 & 0.00 & 2.98 & 21.03 & 4.35 & 3.89 & 0.00 & 0.00 & 0.00 \\
\hline 10. Crab larvae & 0.00 & 0.00 & 0.00 & 6.37 & 0.00 & 4.91 & 0.00 & 0.00 & 1.81 & 0.00 \\
\hline 11. Isopod & 3.05 & 0.00 & 2.69 & 0.00 & 0.00 & 0.00 & 8.47 & 3.64 & 16.95 & 3.55 \\
\hline $\begin{array}{l}\text { 12.Crustacean } \\
\text { appendages }\end{array}$ & 5.22 & 9.90 & 2.69 & 24.33 & 0.00 & 0.00 & 0.00 & 0.00 & 6.03 & 8.94 \\
\hline 13. Shells & 15.31 & 21.28 & 7.05 & 0.00 & 0.00 & 0.00 & 0.00 & 0.00 & 1.81 & 3.97 \\
\hline 14. Eggs & 4.07 & 0.00 & 7.05 & 2.70 & 6.34 & 4.34 & 8.60 & 7.23 & 1.81 & 1.98 \\
\hline 15. Scales & 0.00 & 0.00 & 0.00 & 0.00 & 0.00 & 0.00 & 0.00 & 0.00 & 16.05 & 4.15 \\
\hline 16. Small fish & 0.00 & 0.00 & 0.00 & 0.00 & 0.00 & 0.00 & 0.00 & 0.00 & 3.63 & 6.52 \\
\hline $\begin{array}{ll}17 . & \text { Small } \\
\text { shrimps } & \end{array}$ & 0.00 & 0.00 & 0.00 & 0.00 & 0.00 & 0.00 & 0.00 & 0.00 & 4.03 & 9.37 \\
\hline $\begin{array}{l}\text { 18. Unidentified } \\
\text { fish parts }\end{array}$ & 8.94 & 4.55 & 7.33 & 9.76 & 6.34 & 8.23 & 8.60 & 12.62 & 7.25 & 9.37 \\
\hline Total & 42.46 & 44.19 & 40.33 & 55.67 & 41.21 & 48.72 & 47.37 & 52.11 & 61.67 & 65.54 \\
\hline 19. Debris & 16.57 & 0.28 & 14.37 & 2.98 & 6.85 & 4.34 & 19.21 & 11.50 & 15.58 & 14.05 \\
\hline Total & 100.00 & 100.00 & 100.00 & 100.00 & 100.00 & 100.00 & 100.00 & 100.00 & 100.00 & 100.00 \\
\hline
\end{tabular}

\section{Figures}




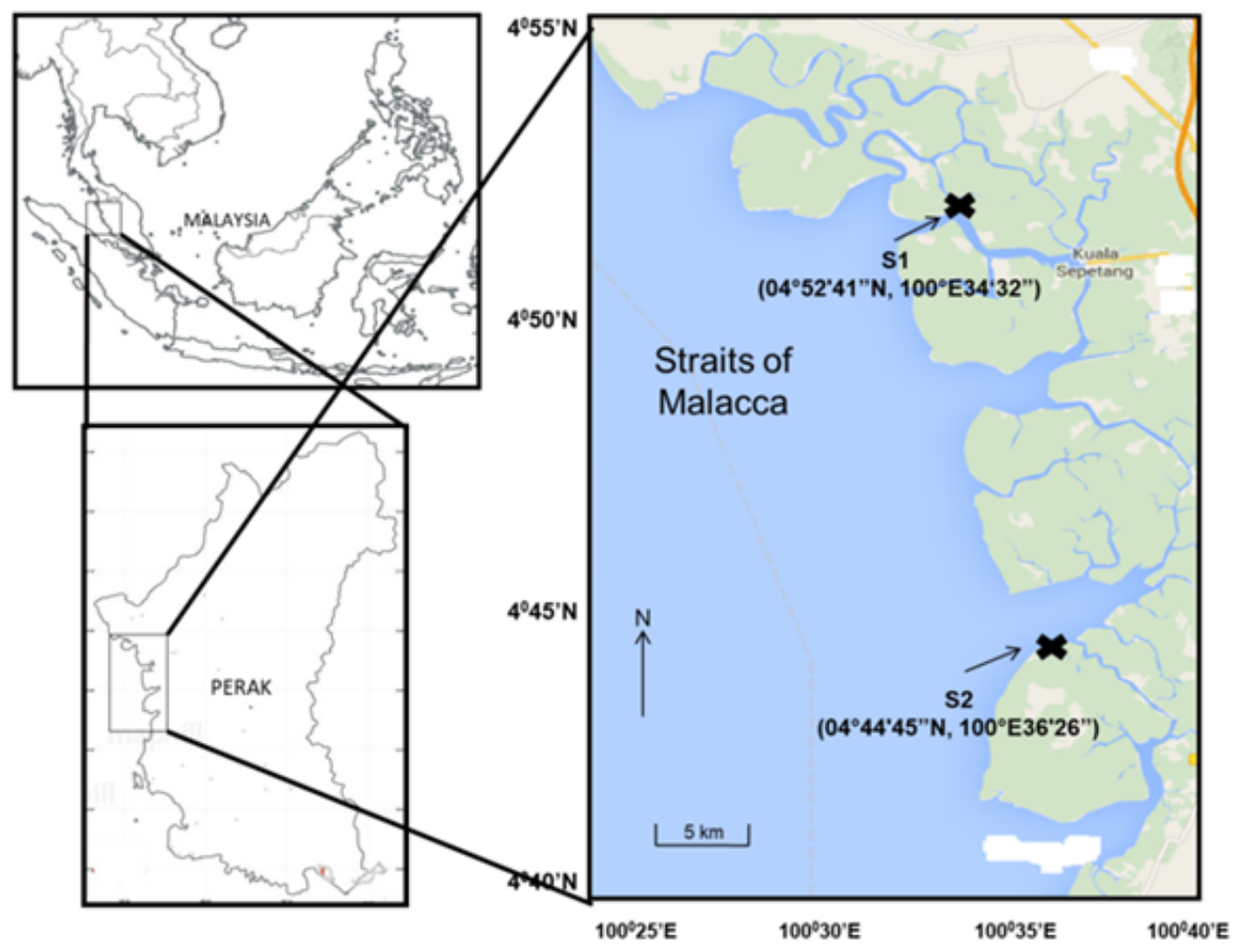

Figure 1

Geographical location of sampling stations (S1 and S2) in Matang Mangrove Estuaries, Perak, Malaysia. Note: The designations employed and the presentation of the material on this map do not imply the expression of any opinion whatsoever on the part of Research Square concerning the legal status of any country, territory, city or area or of its authorities, or concerning the delimitation of its frontiers or boundaries. This map has been provided by the authors.

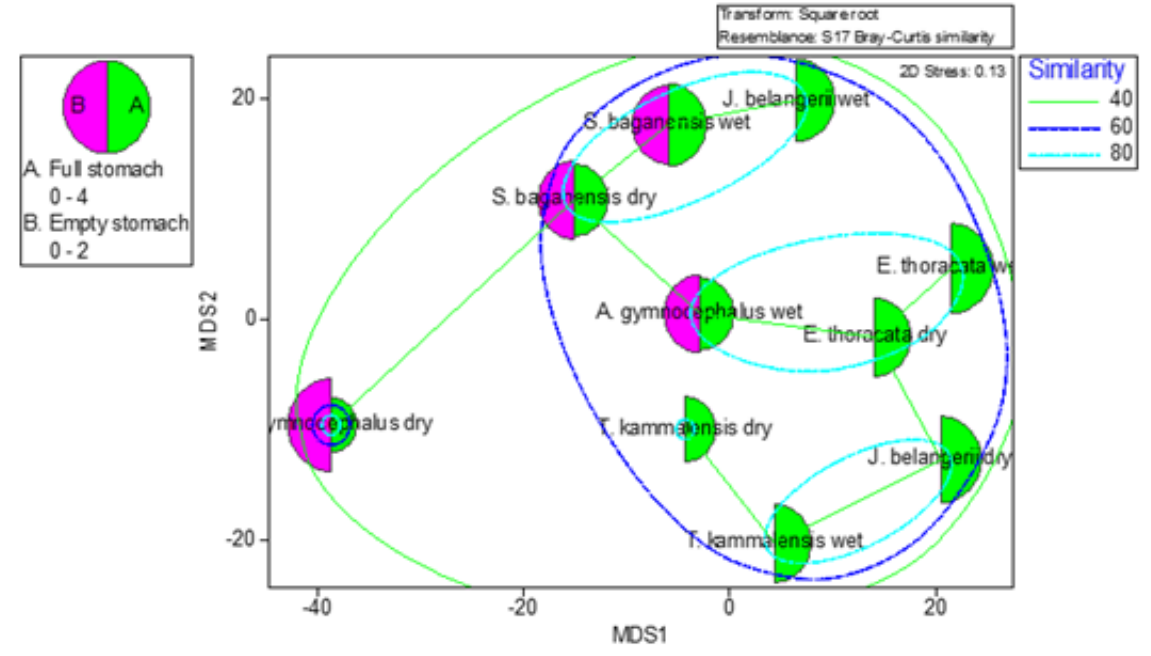

\section{Figure 2}

Ordination plot of stomach fullness for five dominant fish species for using Multi-Dimensional (MDS) analyses in Matang Mangrove Estuaries, Perak, Malaysia (Wet = wet season; Dry = Dry season) 


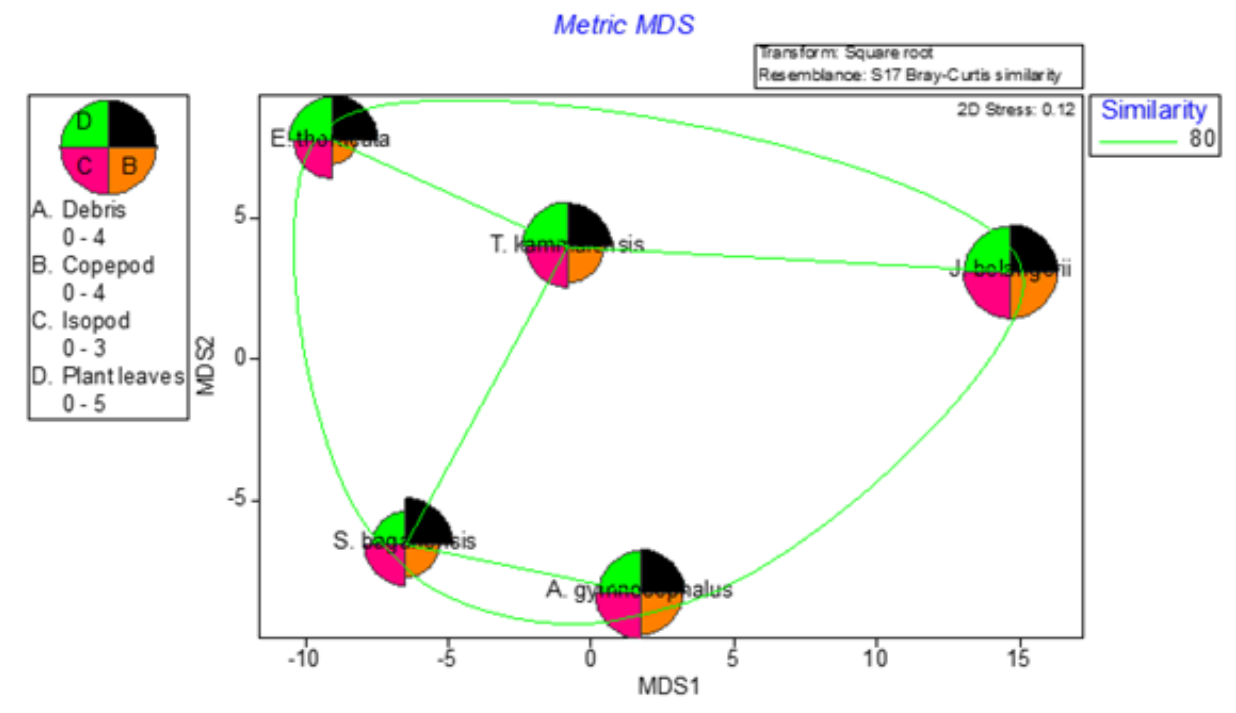

\section{Figure 3}

Ordination plot for dominant diet (debris, copepod, isopod and plant leaves) of five dominant fish species using MultiDimensional Scalling (MDS) analyses in Matang Mangrove Estuaries, Perak, Malaysia

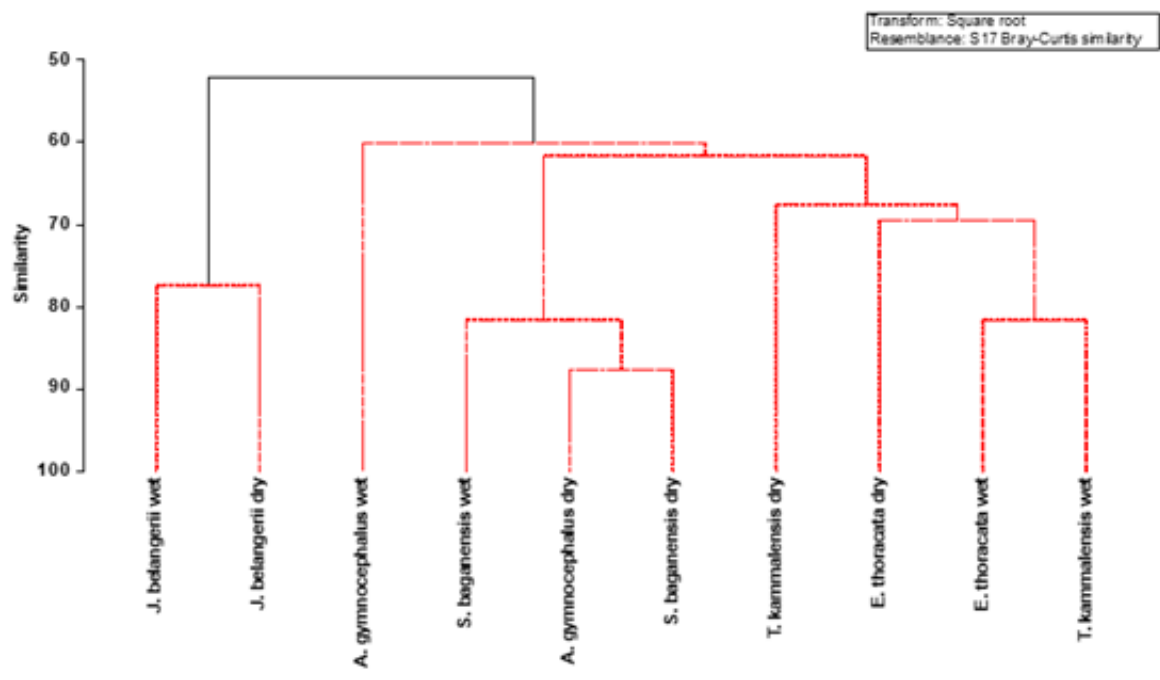

\section{Figure 4}

Dendrogram of cluster analysis showing similarities percentage of diet composition in wet and dry season of five dominant fish species in Matang Mangrove Estuaries, Perak, Malaysia (wet = wet season; dry = dry season) 


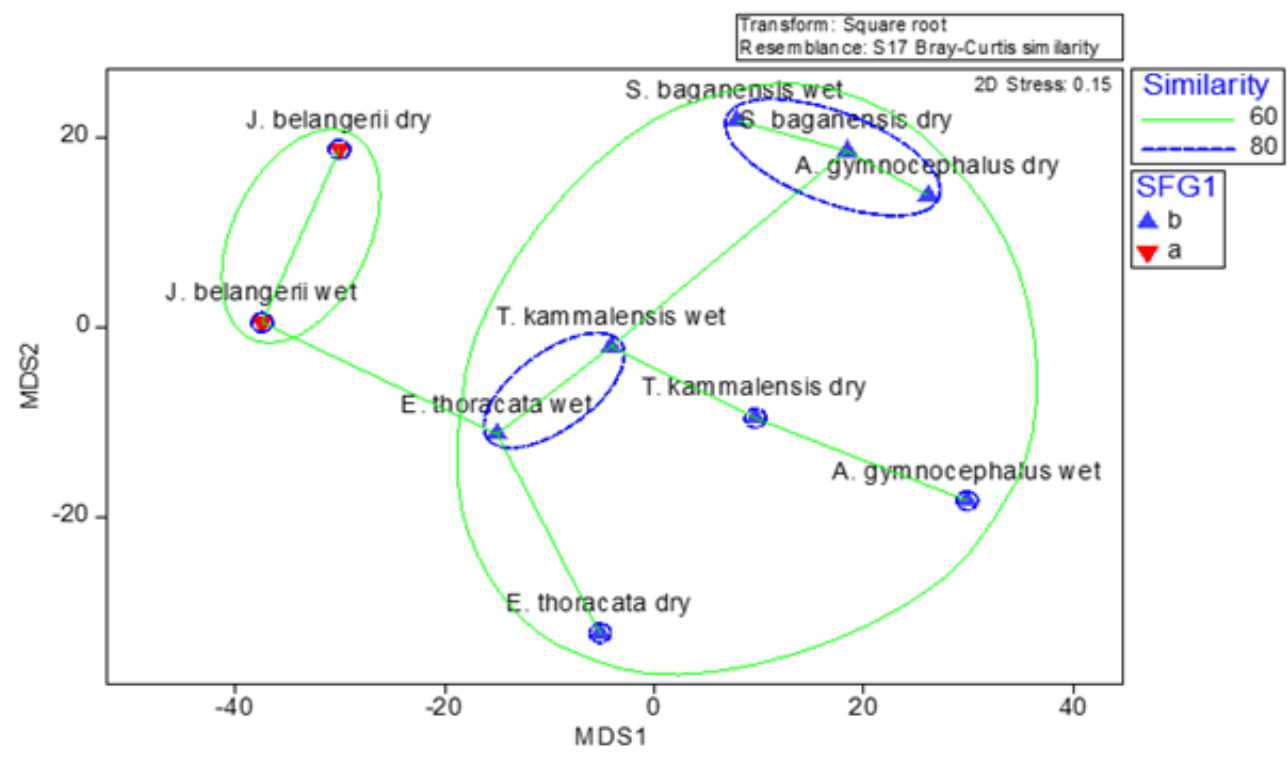

\section{Figure 5}

Ordination plot between wet and dry season for diet composition data of five dominant fish species using Multi-Dimensional (MDS) analyses in Matang Mangrove Estuaries, Perak, Malaysia (wet = wet season; dry = dry season)

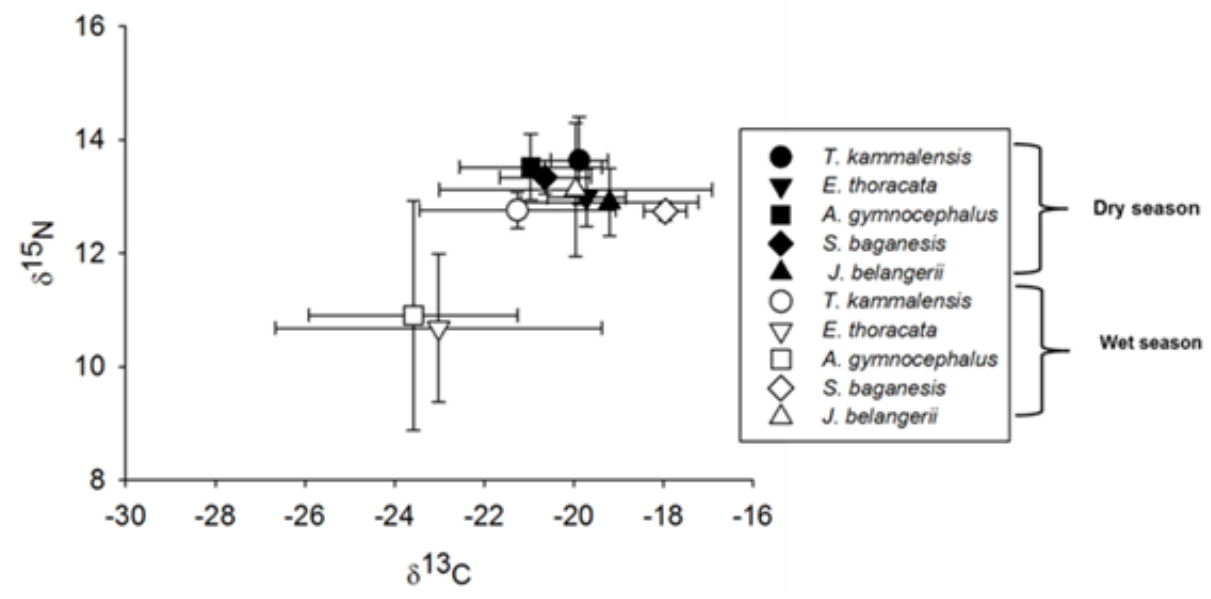

\section{Figure 6}

Dual isotope plot of $\delta 13 \mathrm{C}$ and $\delta 15 \mathrm{~N}$ showing trophic interactions between wet and dry season in five dominant fish species in Matang Mangrove Estuaries, Perak, Malaysia 